\title{
IMPACT OF POWER ELECTRONICS ON GLOBAL WARMING
}

\author{
Gururaj Patil $^{1}$, Shashikant Mathpati ${ }^{2}$, M.S.Aspalli ${ }^{3}$ \\ ${ }^{1}$ Power Electronics, P.D.A College of Engineering, Gulbarga - 585102, India \\ ${ }^{2}$ Power Electronics, P.D.A College of Engineering, Gulbarga - 585102, India \\ ${ }^{3}$ Power Electronics, P.D.A College of Engineering, Gulbarga - 585102, India
}

\begin{abstract}
Global energy consumption is increasing rapidly due to increase in world's population and changes in their living standards. Most of this energy comes from fossil fuels. The burning of these fossil fuels lead to emission of Green House Gases (GHG) causing global warming. This paper introduces the impact of power electronics to reduce the global warming and to utilising the renewable sources.
\end{abstract}

Key words: Global warming, Renewable energy, Power electronics.

$* * *$

\section{INTRODUCTION}

The global energy demand is increasing significantly due to growing population, improvement in the living standard of the humanity, industrialization of the countries. The primary source of energy is fossil fuel. Fossil fuel burning causes environmental pollution problems, particularly the Global warming by the emission of green house gases. The safe and environment friendly renewable energy sources, such as wind, solar etc are getting more importance in order to decrease the global warming problems and also expected to replace the conventional energy resources in future. Power electronics technique is playing a important role in global energy conservation and helping the environmental pollution control and reduction in global warming problems. About $20 \%$ of global energy consumption can be reduced by using power electronics techniques. Another $20 \%$ can be saved by reducing the losses by using conservation methods.

\section{GLOBAL ENERGY OUTLOOK AND GLOBAL WARMING PROBLEMS}

\subsection{Global Energy Outlook}

Recent estimations show that the global energy consumption doubles during the period 2008-2050. The energy resources that we are having are limited. The energy resources are depleting or reducing day by day. Based on present availability and rate of consumption the global energy depletion curves for coal, oil, natural gas and nuclear fuels are as shown in Fig. 1.

Now a day the coal energy demand is increasing faster than any other energy sources, and expected to peak around during period 2070, will lasts up to 200 years. The oil and natural gas reserves are expected to last around 100 and 150 years respectively [6].
The global energy generation from different sources is shown in Fig.2. Now a day's renewable energy sources are fastest growing sources with $3 \%$ increase in consumption per annum.

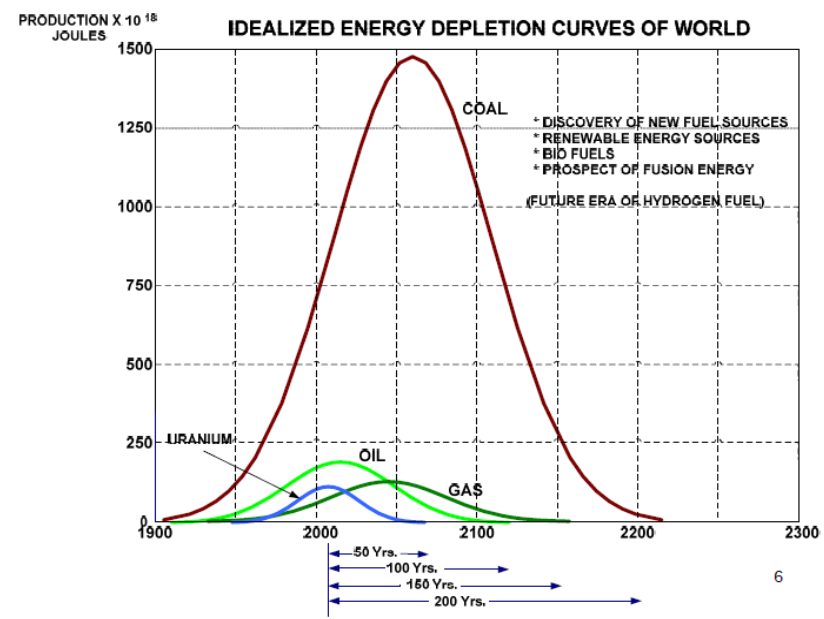

Fig. 1 Depletion curves [6]

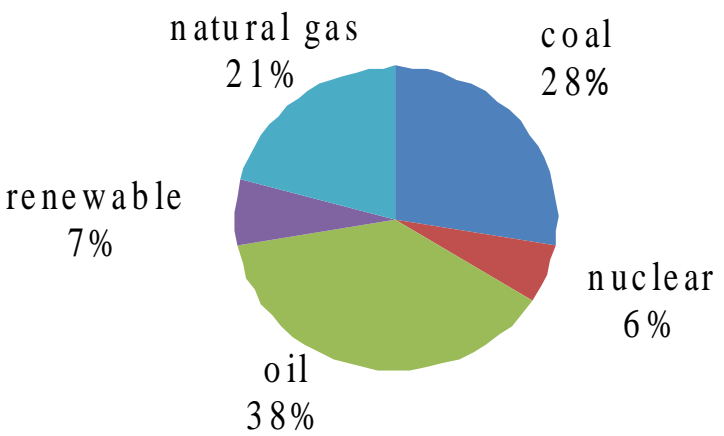

Fig. 2 Global energy generation [6] 


\subsection{Global Warming Problems}

Global warming is the rising in the temperature of Earth's atmosphere and oceans due to increase in the concentrations of green house gases produced by deforestation and burning of fossil fuel. Global warming could impact on agriculture, human health, energy use, transportation and industry [1]. Accumulates the heat on Earth's surface due to GHG concentrations and raises the temperature. This causes:

- Adverse effect on world climate.

- Melting of glaciers and polar ice caps.

- In the tropical countries near the equator damages agriculture and vegetation due to drought.

- $\quad$ Arising the cyclone, heavy rain fall and floods.

- Spread of disease, loss some animal species.

- Sea water acidity increases.

According to UN survey, some of scenarios due to global warming are [1]:

- India's agricultural production will decrease by $38 \%$ by 2080 due to absence of water.

- $50 \%$ of Bangladesh will be under water in 300 years displacing $75 \mathrm{M}$ people.

- Within 100 years several Island nations in the Pacific will be under water.

- In Antarctica and Greenland regions melting of ice will cause ocean level rise by $200 \mathrm{ft}$.

- In the world ocean level increases by $210 \mathrm{ft}$. due to melting of ice.

- $\quad$ Arctic regions will becomes free of ice by 2070 .

- If today fossil fuel burning is completely stopped, ocean level will rise by $4.6 \mathrm{ft}$. in next 1000 years.

\section{IMPACT OF POWER ELECTRONICS}

Power electronics helps to improve the energy efficiency and generation of environmental friendly energy or green energy. Power Electronics has multi-disciplinary nature because it is an exciting as well as complex technology. Currently the electric power engineer's uses maximum Power Electronics technique shown in Fig.3.

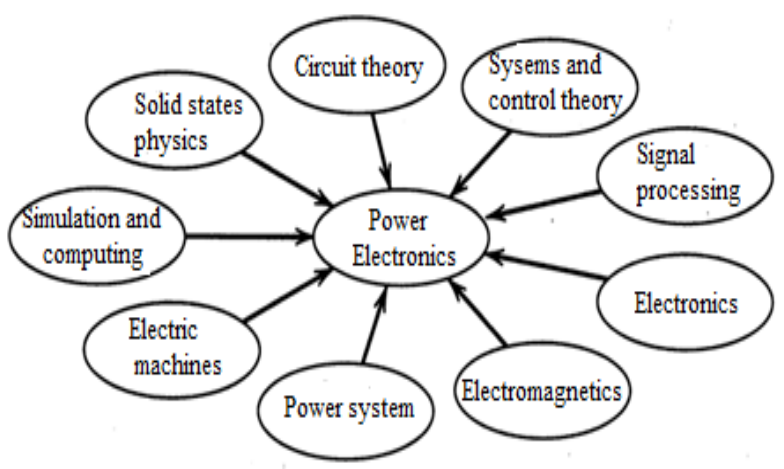

Fig. 3 Multi-disciplinary nature of power electronics [7]
The power electronics interfaces the electronics device circuits, power static and rotating equipments, and continuous and discrete control system and it is in shown in Fig. 4 [7].

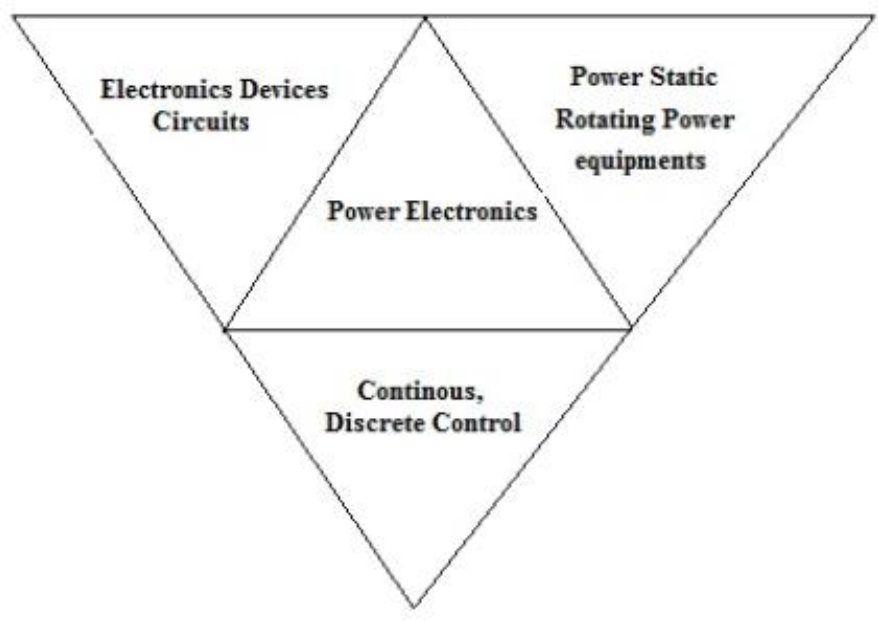

Fig. 4 Electronics and Power interface [7]

The power electronics techniques used in uninterruptible power supply (UPS) systems, dc and ac regulated power supplies, lighting and heating control, power line static VAR compensators, active harmonic filters, high voltage dc (HVDC) systems, electronic welding, fuel cell (FC) and photovoltaic (PV) power conversion, high-frequency heating, solid state dc and ac circuit breakers and motor drives. The area of motor drive may include applications in computers and peripherals, transportation like electric/hybrid vehicle, solid state starters for motors, home appliances, pumps and compressors, textile and paper mills, wind generation system, air-conditioning and heat pumps, rolling and cement mills, robotics and machine tools, ship propulsion etc. In addition to applications in energy systems and industrial automation, power electronics is now playing a significant role in global energy conservation that is helping environmental pollution control indirectly, i.e. solving the global warming problem.

\subsection{Solar Energy}

The maximum use of solar energy is dependent on power electronics. The process of converting solar energy into electrical energy by use of solar cells called the photovoltaic effect. The efficiency of a solar cell is depends by its ability to convert available sunlight into usable electrical energy. Solar cells must have large surface areas so as to produce large amount of power. The main role of power electronic interfaces for the PV systems is to convert the generated DC voltage into a suitable AC for utility connection and consumer use [3]. The generated DC voltage magnitude is required to be boost to a higher value by using DC-DC converters (chopper) before converting them to the utility AC. The DC-AC inverters are 
then used to convert the voltage to required frequency AC. The Fig.5 shows the Three phase arrangement of photovoltaic cells.

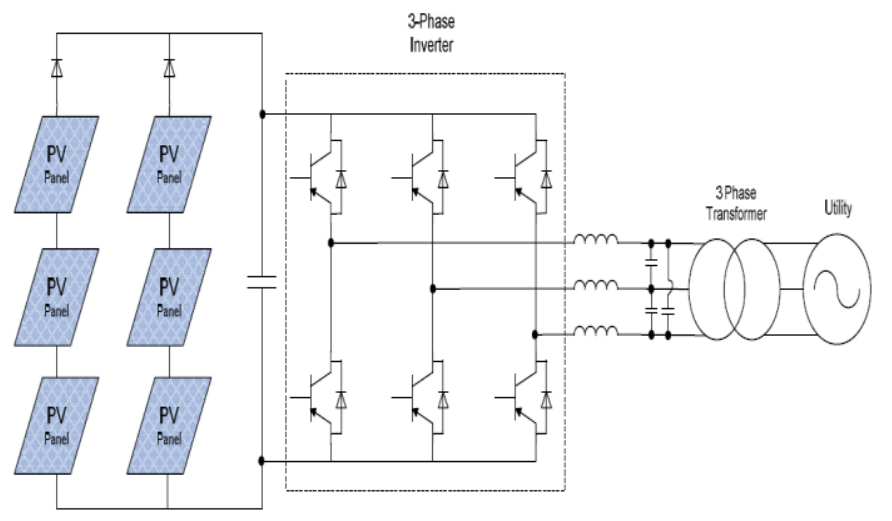

Fig. 5 Three-phase photovoltaic power electronics [3]

\subsection{Wind Energy}

Wind energy is source of clean energy. Wind turbine system converts the kinetic energy of the wind into mechanical energy that can be converted into electrical energy with a generator. The wind energy is a biggest energy in renewable energy sector. From last 20- 25 years, the grid connected wind capacity has doubled and the cost of power generated from wind energy based system has reduced to one-sixth of the corresponding value in the early 1980 s [2].

The important features considerations with wind energy conversion system are:

- Available wind energy.

- Type of wind turbine employed.

- Type of electric generator.

- Power electronic circuitry used for interfacing with the grid.

In the early days the wind turbine generators includes fixedspeed wind turbines with conventional induction generators. The induction generators are directly connected to the grid without power electronics (PE) interface due to which its operation was limited in a narrow wind-speed range. These wind turbines operates at a constant speed and adjust the rotor speed by controlling the pitch of the wind turbine blades. The induction machine requires reactive power can be supplied from the utility grid or by capacitors connected at the machine terminals.

The wind turbine system with partially rated power electronics requires wound-rotor induction machines where both the stator and rotor windings are accessible. Power from the spinning rotor is collected via slip rings. The output of the generator is passed through a PE based rectifier and inverter system, transforming the variable frequency power into grid compatible $\mathrm{AC}$ power with the proper voltage and frequency.
The wind turbine system uses full-scale power electronics for interfacing the wind turbine to the grid. In these systems requires conventional or permanent magnet synchronous generators to convert the wind turbine power to a variable voltage and variable frequency output that depends on wind speed. A PE based rectifier and inverter are then used to convert the full rated output from generators to power that is compatible with the utility system. Fig.6 shows the variable speed wind energy conversion system.

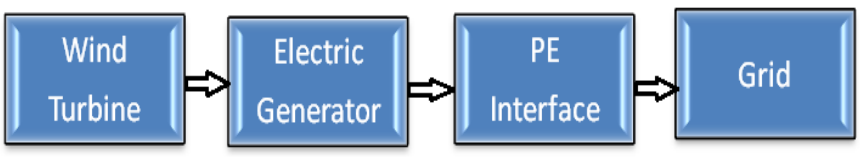

Fig. 6 Variable speed wind energy conversion system [1]

\subsection{Fuel Cell System}

A fuel cell is an electro-chemical device which converts the chemical energy into electrical energy. The most significant advantages of fuel cells are low emissions of green house gases and high power density. The efficiency of a fuel cell is also high i.e. in the range of $40 \%$ to $60 \%$. If the waste heat generated by the fuel cells is used for cogeneration, the overall efficiency of such a system could be as high as $80 \%$.

The two methods of obtaining usable ac output from the fuel cells are shown in below figures. The Fig.7 (a) shows the dc output from the fuel cell is first inverted using a conventional voltage source inverter (VSI) or a current source inverter (CSI) and then the ac voltage is stepped up employing a transformer. The Fig.7 (b) shows the fuel cell output voltage is stepped up employing a dc-dc converter and then the stepped-up dc voltage is inverted to line frequency ac. Conventionally this method has been more popular because of the absence of transformer and the controllability of the dc-dc converter.

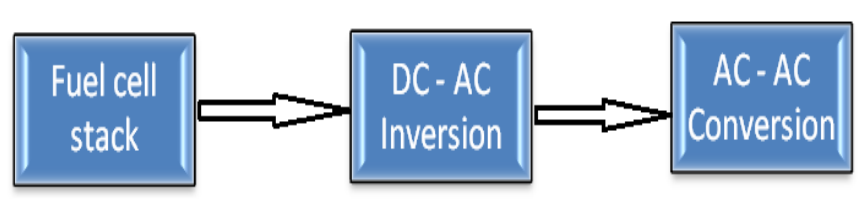

(a)

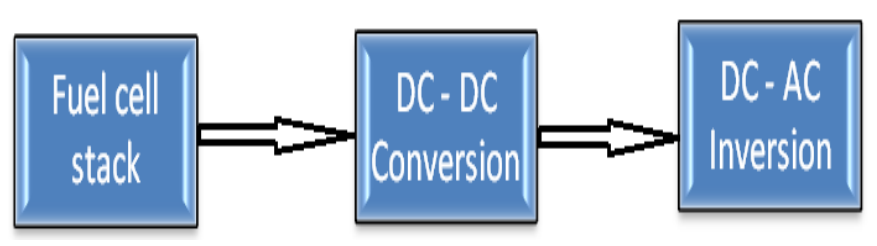

(b) 


\subsection{Variable Frequency Drives}

In a variable frequency drive, motor efficiency can be improved by machine flux programming at light load and reduced speed. Power electronics based load proportional speed control in airconditioning can save $30 \%$ of energy, compared to the traditional thermostatic control. Using Variable Frequency Drive (VFD) we can control the speed of motor depending upon application speed therefore unnecessary speed will control and temperature emission by motor will also reduce. The additional cost of power electronics can be recovered by saving energy in a period depending on the cost of electricity.

\subsection{Lighting}

Power electronics based high frequency compact fluorescent lamps (CFLs) are much more i.e. four times more efficient than traditional incandescent lamps and giving longer life. Light dimming control method of CFL can further improve energy efficiency. In the future the CFLs are completely replacing the incandescent lamps. The Solid state LED lamps with higher efficiency and longer life compare to both incandescent lamps and CFLs.

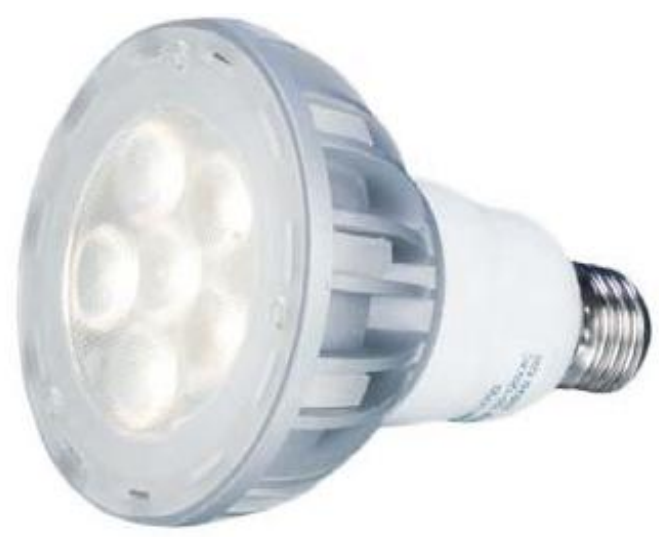

Fig. 8 A solid-state LED lamp [1]

\subsection{Electric/Hybrid Vehicles}

In Electric Vehicles (EVs) battery is the very important component because it stores energy. The dc is converted to variable frequency variable voltage ac with the help of power electronics to run the propulsion motor (induction or synchronous motor). During braking energy can be regenerated and restore in battery. The range in EV is limited by battery capacity, but in Hybrid Electric Vehicles (HEVs), there is no such problem. Unfortunately, battery technology today is not yet mature. It is bulky, expensive, has limited life cycle and long charging time. The Ni-MH batteries have been used extensively, currently because it has large storage density, but expensive. There is large emphasis on Li-ion battery research in recent years. Presently Most of EVs/HEVs uses Li-ion batteries.

\section{CONCLUSIONS}

Global energy demand is increasing continuously, major part of these energy demands are fulfilled by the non-renewable energy sources like coal, natural gas, oil etc. These energy sources may last for another 200 years. Also generation of power by these sources leads the emission of green house gases which increases the earth's temperature and causes global warming. Renewable energy sources (solar and wind) play important role as energy sources in future. Power electronics technology will play very important role in energy saving. Green and Clean energy generation is made possible using power electronics and reduction in green house gas emissions, hence reduction in global warming. Saving energy system gives a direct financial benefit, particularly where the energy cost is high. The extra cost of power electronics in energy saving system can be recovered within a reasonable period depending on the cost of electricity. The significance of power electronic was discussed to make the role of power electronics more clear in terms of advancement in inverters; microcontrollers and high temperature solid state fuel cells. Due to the polluting nature of conventional combustion motors the significance of Electric Vehicle in mitigating the environmental issues was presented with an emphasis on power electronics.

\section{REFERENCES}

[1] Ahmed. F. Zobaa1, Bimal.K.Bose, "Renewable Energy, Global Warming Problem and Impact of Power Electronics," ICREPQ, Las Palmas de Gran Canaria (Spain), 13th to 15th Apr.2011.

[2] Frede Blaabjerg, Ke Ma, "Future on Power Electronics for Wind Turbine Systems," IEEE Trans, vol. 1, no. 3, Sept. 2013.

[3] W. Kramer S. Chakraborty, B. Kroposki, and H. Thomas, "Advanced Power Electronic Interfaces for Distributed Energy Systems," Technical report, NREL/TP-58142672 Mar. 2008.

[4] Satyendra V,K.B.Mohd.Umar Ansari, Goldy Sharma, "Importance of power electronics in renewable energy systems," ISSN Vol.02,Oct. 13

[5] Christian Ifeanyi ENETE, Michael Oloyede ALABI, "Potential Impacts of Global Climate Change on Power and Energy Generation," Journal of Knowledge Management, Economics and Information Technology, Oct. 2011.

[6] Bimal k. Bose, "Energy, Environment and Importance of power electronics," Recent Researches in Environmental and Geological Sciences, Jan. 2008.

[7] N. Mohan, T. M. Undeland, and W.P. Robbins, Power Electronics: converters, Applications and Design, Third edition, John Wiley, 2003. 